\title{
8th International conference on ethics education, Zagreb, Croatia, July 3-5, 2020
}

Published online: 16 March 2020

(C) Springer Nature Switzerland AG 2020

The next international conference on ethics education will take place in Zagreb, Croatia. The conference will be organized by the International Association for Education in Ethics (IAEE) in cooperation with the Andrija Stampar School of Public Health, School of Medicine, University of Zagreb, The Croatian Bioethics Society, and the Croatian Centre for Excellence for Integrative Bioethics.

The theme of the conference is: Ethics Education, Interdisciplinarity and Pluriperspectivism. The conference will cover numerous fields of ethics education: bioethics, medical ethics, nursing ethics, pharmacy ethics, dental ethics, science ethics, environmental ethics, philosophical ethics, religious ethics, business ethics, journalism ethics, engineering ethics, and sports ethics. There will be ample opportunity to address cultural and religious diversity in ethics teaching, as well as the relations between ethics, science, religion, and history.

Papers presented at the conference can be elaborated into scientific articles and submitted to the International Journal of Ethics Education. The journal is included in membership of the International Association for Education in Ethics. Members of IAEE also enjoy a reduced registration fee for the conference.

For detailed information about the conference: www.bioetika.hr/iaee2020/ or contact the organizer Dr. Ana Borovecki (aborovec@gmail.com; abor@mef.hr).

Publisher's note Springer Nature remains neutral with regard to jurisdictional claims in published maps and institutional affiliations. 